\title{
Effect of Implementing Meaningful Recognition Program on Head Nurses 'Knowledge and Practice and Nurses' Satisfaction
}

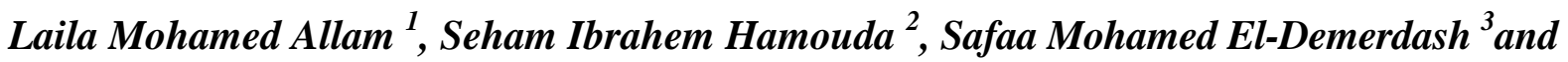 \\ Heba Kamal Obied ${ }^{4}$ \\ ${ }^{1}$ MSC Nursing Administration, Faculty of Nursing, Tanta University \\ ${ }^{2,3}$ Professor of Nursing Administration, Faculty of Nursing, Tanta University \\ ${ }^{4}$ Assistant Professor of Nursing Administration, Faculty of Nursing, Tanta University
}

\begin{abstract}
Background: Staff nurses are in need for praise and recognition because of its impact on their performance and their job satisfaction. Aim:evaluate effect of implementing meaningful recognition program on head nurses' knowledge and practice and nurses' satisfaction. Method: Quasi- experimental design was used to conduct the study at Tanta International Teaching Hospital. The subjects of the study consisted of all (35) head nurses and 250 staff nurses were working in the above mentioned setting. Three tools were utilized: Tool I: Head Nurses' Meaningful Recognition Process Observation Checklist. Tool II Head Nurses' Meaningful Recognition Process Knowledge Questionnaires. Tool III: Staff Nurses' Satisfaction of Head Nurses 'Practice of Meaningful Recognition Process questionnaire. Results: $91.4 \%$ of head nurses had unsatisfactory level regarding overall practice of meaningful recognition process at pre educational program, decreased to $14.3 \%$ post educational program and reached $42.9 \%$ at 3 months post educational program. $77.1 \%$ of head nurses had poor level of meaningful recognition knowledge at pre educational program, improved to be $88.6 \%$ good level at post and $82.9 \%$ post 3 month of the meaningful recognition educational program. Statistical significant positive correlation was found between head nurses' overall knowledge of meaningful recognition process, its subscales and their overall practice of meaningful recognition process and its subscales with their staff nurses' overall satisfaction of head nurses' practice of meaningful recognition process and its overall subscale at $p \leq 0.05$. Conclusion:Head nurses at Tanta International Teaching Hospital knowledge and practice positively improved post educational program of meaningful recognition, thus staff nurses had high level of satisfaction post program than pre program . So, nurse managers should pay more attention to the vital role of meaningful recognition as a valuable strategy for upgrading nurses' job satisfaction, and develop policies and practices that foster meaningful recognition among head nurses.
\end{abstract}


Key words: Head nurses, Meaningful recognition, Staff nurses, Satisfaction.

\section{Introduction}

Meaningful recognition has been delineated by the American Association of Critical Care Nurses (2005) ${ }^{(1)}$ as one of the keys for establishing and maintaining healthy work environment for nurses. Head nurses play a critical role in improving nurses work place, by advocating for the inclusion of staff nurses' recognition into daily operations. The head nurses' recognition behaviors strongly influence the job satisfaction of nurses. ${ }^{(2)}$ The general acknowledgement or confirmation of a given occurrence or performance is referred to as recognition. ${ }^{(3)}$ Appropriate recognition behavior by the head nurses is an extremely important practices for increasing the nurses' motivation and the prevention of burnout and the promotion of retention. ${ }^{(4)}$

According to Cherian (2017) ${ }^{(5)}$ meaningful recognition is the process of acknowledging one's behaviors and the impact these actions have on others, ensuring the feedback is relevant to the recognized situation and is equal to the person's contributions. Recognition is only meaningful when it is relevant to the person being recognized and genuine appreciation. (6) Meaningful recognition according to
Froman $(2010){ }^{(7)}$ has been associated with elevating one's self- esteem which can in

turn impact staff nurses' job satisfaction. Staff nurses consistently rate recognition from patients, families, and other nurses including head nurses as the most meaningful. It reaffirms staff nurses' positive contributions, emphasizing the impact of nursing care and increasing awareness of staff nurses' unique contributions to health care. ${ }^{(8)}$

Moreover, meaningful recognition according to American Association of Critical Care Nurses $(2005)^{(1)}$ and Psychological Associates and Daisy Foundation (2009) ${ }^{(9)}$ contributes directly to staff nurses' job satisfaction to which in turn results into reduced medical errors, conflict, stress them and effective delivery of patient care. ${ }^{(10)}$ Meaningful recognition that is conditional foundation, timely, informal and, or formal acknowledgement of a nurse's behavior or effort is a powerful reign forcer to improve performance and the behavior will be repeated in thefuture. (11)

Head nurses can have an impact on nurses' satisfaction through the practices of meaningful recognition of positive nurses' 
efforts and accomplishments. (12) These practices are private verbal feedback, public acknowledgment, written acknowledgment, opportunities for growth and participation, and compensation. Private verbal feedback is a face to face discussion occurs between the head nurses and staff nurse whereby the head nurse provides positive feedback for day to day operation such as handling situations well, or giving outstanding patient care. Public acknowledgment, the head nurse provides positive feedback in public in front of others nurses, peers, senor administration, physician, and other health care professionals regarding the good work done by the nurse. ${ }^{(13)}$

Written acknowledgement, the head nurse gives feedback in a written form to staff nurses regarding achievement and performance. For example, outstanding care is acknowledged by a litter given to staff nurse and a copy placed in the file. Opportunities for growth and participation, the head nurse push nurses by providing opportunities for participation and decision making e.g. head nurse ask nurses to participate in planning for unit and consults with them on important patient care. Regarding compensation, exceptional performers can be compensated by given a day off with pay to attend conference. ${ }^{(14)}$

\section{Significance of study:}

Recognition is an important aspect of keeping staff nurses. Unfortunately, although it is a simple and cost-effective strategy, it is often overlooked as a viable solution to retention problems. So, head nurses require much more training and educational resources to become more effective recognition givers ${ }^{(15)}$.

Result of Eldemerdash (2006) ${ }^{(16)}$ indicates that head nurses need for education program to teach them importance of offering sincere positive recognition for their staff nurses team. Little research has been done that focuses on content or process of providing recognition to nurses. Nurses who are not recognized feel invisible, undervalued, unmotivated and disrespected. Lack and absent of recognition has been ranked as one of the primary cases of discontent in nursing and it can potentially affect everyone, especially those people most depend on nurses' performance, their patients. So, Head nurses must be knowledgeable about these practices of meaningful recognition and must be sensitive to staff nurses' needs to incorporate these practices in their management role, as recommended by Good and Bligen (1993) ${ }^{(13)}$; Eldemerdash and Ghadery (2014) ${ }^{(17)}$. 


\section{Aim of the study}

The aim of the study is to:

Evaluate effect of implementing meaningful recognition program on head nurses' knowledge and practice and nurses' satisfaction.

\section{Research Hypothesis}

Head nurses' knowledge and practice is expected to be improved after implementation of the program about meaningful recognition, and staff nurses' satisfaction will be improved.

\section{Subjects and methods}

\section{Study Design}

Quasi experimental design was used to achieve the aim of the present study. preposttest utilized to evaluate the impact of educational intervention on the study subject.

\section{Setting}

The study was conducted at Tanta International Teaching Hospital. It is 279 bed capacity, including the following units Surgical and Medical, Intensive Care Units ICUs, Operating Rooms (OR), Dialysis, Incubators, Neurological, Medical, Urological, Oncology, Emergency, Orthopedic, Pediatric, Obstetrics and Gynecology, Endoscopy, Obesity \&Thinness and Bone Marrow Transplantation units. In addition to
Outpatient Clinics, Sterilization, Blood Bank, Laboratory, Physiotherapy, Mammography, Electrography, Magnetic Resonance Imaging (MRI), Cat Scan CT, and X- ray.

\section{Subjects}

The study subjects consisted of all (35) head nurses and all (250) staff nurses (76 from ICUs and 174 from general units) were working in all units of Tanta International Teaching Hospital and available at the time of data collection.

\section{Tools of data collection}

To achieve the aim of this study three tools were used:

\section{Tool I: Head Nurses' Meaningful} Recognition Process Observation

Checklist. This tool was developed by researcher guided by EL-demerdash and Ghadery (2014) ${ }^{(17)}$ and Willingham (2014) (18) and recent related literatures ${ }^{(5,13,15)}$. It was used to test the head nurses' knowledge about meaningful recognition it consisted of two parts:Part (1): Head nurses' personal characteristics including age, marital status, years of experience, education qualification and department.

Part two: Head Nurses' Meaningful Recognition Process Observation Checklist to collect data from head nurses about their meaningful recognition process 
at Tanta International Teaching Hospital. This part included 84 items categorized in five subscales:private verbal feedback, public acknowledgement, written acknowledgement, opportunities for growth and participation, and compensation.Head nurse's responses were measured on two points ranging from (2) done to (1) not done. The total scores were converted into levels to display head nurses' recognition practice and classified into:Satisfactory meaningful recognition practice $\geq 60 \%$, and Unsatisfactory meaningful recognition practice $<60 \%{ }^{(17)}$. Tool(II): Head Nurses' Meaningful Recognition Process Knowledge Questionnaires. This tool was developed by the researcher based on recent related literature $(24,28,39,40,42,148)$ to collect data about meaningful recognition process knowledge among head nurses. It consisted of two parts: Part one: subjects' characteristics included age, marital status, years of experiences, educational level, and department. Part two: Head nurses' Meaningful Recognition Process Knowledge Questionnaire. This part covered, definition, important, criteria, type, principles of meaningful recognition process, forms of meaningful recognition process and head nurses' practice for meaningful recognition process. It included 99 questions divided into 19 items questions in the form of multiple choices, 52 items true and false, and 28 items in the form of Multiple Choice Questions. These questions cover the five dimensions of recognition process. Each item was allotted a score of (1) for correct answer, and (0) for wrong answer. The total scores were converted into percent scores to determine the levels of head nurses' knowledge as follows: good knowledge level > 75\%, faire knowledge level $60-75 \%$, and poor knowledge level < $60 \%$.

\section{Tool (III): Staff Nurses' Satisfaction regarding Meaningful Recognition}

Process. This tool was developed by the researcher guided by El-demerdash and Ghadery (2014) ${ }^{(17)}$, Willingham (2014) ${ }^{(18)}$ and other related recent literature ${ }^{(5,13,15)}$. It was used to identify nurses' satisfaction about meaningful recognition that received from their head nurses. It included the same items in tool one. This tool consisted of two parts, Part one: Nurses' characteristics included, age, gender, marital status, educational level, years of experience and department. Part two: Nurses' satisfaction of meaningful recognition process questionnaire: It was 
used to collect data from nurses about meaningful recognition that they receiving from their head nurses. It was included the same items in the tool one. Nurses' satisfaction of meaningful recognition process questionnaire was measured on 5points Likert Scale (1-5) ranging from strongly agree to strongly disagree, strongly agree (5), agree (4), neutral (3), disagree (2), and strongly disagree (1). The total scores were classified into levels to assess nurses' levels of satisfaction as follows: high level of satisfaction $>75 \%$, moderate level of satisfaction $60 \%-75 \%$ and, low level of satisfaction $<60 \%{ }^{(17,18)}$.

\section{Method}

\section{Data collection}

The data was collected from Tanta International Teaching Hospital by the researcher After obtaining official permission from responsible authorities. Tool I and III were presented to a jury of 9 experts in the area of specialty to check content validity, it was $98.4 \%$ for tool (I) and $95.4 \%$ for tool (III). A pilot study was carried out on a sample of $(10 \%) 4$ head nurses, and 25 staff nurses, they excluded from the main study sample during the actual collection of data. The reliability of tools was tested by using Cronbach Alpha
Coefficient test, it $95.4 \%$ for tool (I) and (III).

Head nurses' meaningful recognition process observation checklist was done by the researcher pre, post and three-month post implementation of the program. The researcher observed each head nurse at a time during the day shift. Head nurses' knowledge about meaningful recognition was assessed by tool (II) pre, post and three-month post implementation of the program. The researcher met staff nurses individually during their work shifts to distribute tool (III) pre, post implementation of meaningful recognition program. The staff nurses recorded their answers in the presence of the researcher.

Duration of data collection lasted 11 months beginning from march 2018 until January 2019. The assessment phase (pretest) initiated from march 2018 and followed by period of preparation of the program. Implementation of the program and posttest beginning from October 2018 and finished in the end of the same month. Follow up phase within 3 months beginning from November 2018 till the first week of February 2019

\section{Construction of educational program}

The main objective of the program was to improve head nurses' knowledge and 
practice regarding meaningful recognition. After determining objectives of program, the content was specially designed, methods of teaching and evaluation were identified. The content designed to provide knowledge and skills related to meaningful recognition. The program contents were divided into six sessions encompass; overview on meaningful recognition process, privet verbal feedback, public acknowledgement, written acknowledgement, opportunity for growth and development, and compensation.

\section{Teaching-learning strategies and aids}

Selection of teaching methods were governed by the subjects themselves and content of the program. The methods used were lecture, group discussion, case study, example from life and work situations. The teaching aids used in the program were data show, flow sheet, handouts, pen and papers

\section{Implementation of program}

The study was carried on (35) head nurses. Head nurses were divided into 6 groups. The program time was 12 hours for each group. One session every day for 6 days, every session was 2 hours. They preferred to start the session after finishing necessary work. The program theoretical sessions were held in the conference room and head nurses room at Tanta International Teaching Hospital.

\section{Evaluation of the educational program:}

Evaluation of head nurses preprogram was done in the form of pretest administered to them. At the end of the program, a post test was carried out for only 35 head nurses. Evaluation of head nurses after threemonths post program was done using tools (I, II) used in pre and posttest in order to determine the knowledge retention and practice of head nurses from educational program.

\section{Ethical consideration}

The aim of the study was explained to head nurses to gain their cooperation, verbal consent for their participation in the study was obtained and they had the right to withdraw. They were informed about the confidentiality of their information.

\section{Results}

Table (1): Represents the distribution of the head nurses according to their characteristics. It was observed that, more than forty $(45.7 \%)$ of head nurses aged 40 years with mean $42.31 \pm 6.21$, high percent $(62.9 \%)$ of them have years of experience ranged from 15 to 25 years of experience with mean $20.31 \pm 6.21$. The majority $(80.0 \%)$ of them were married. In relation 
to, department, more than forty $(45.3 \%)$ of head nurses working in general units, less than forty $(37.1 \%)$ of them working in special units, while few percent $(8.6 \%)$ of them working in other department. Regarding level of education more than seventy

Figure (1) describes the overall levels of head nurses' practice of meaningful recognition process pre, post and 3 months post educational program. It was observed that, the overall levels of head nurses' practice of meaningful recognition process were improved significantly at $\mathrm{P}$ $\leq 0.05$ post educational program and at 3 month post educational program than pre educational program. Majority (91.4\%) of head nurses had unsatisfactory practice level regarding meaningful recognition process at pre educational program decreased to low percent $(14.3 \%)$ post educational program and reached $42.9 \%$ at 3 months post educational program.

Table (2): Represents difference of the head nurses' practice level of meaningful recognition process at pre, post, and at 3 months post educational program. It was observed that levels of head nurses' practice of private verbal feedback, public acknowledgment, written acknowledgment, opportunity for growth and participation, and compensation subscales of meaningful recognition process were improved significantly post and at 3 month post educational program than pre educational program at $\mathrm{p} \leq 0.001$. Regarding private verbal feedback subscale of meaningful recognition process. At pre educational program the majority $(94.3 \%, 91.4 \%, 88.6 \%$, and $77.1 \%$ ) of head nurses had unsatisfactory level of practice of written acknowledgment, opportunity for growth and participation, public acknowledgment and compensation subscales of meaningful recognition process respectively, which decreased to $20 \%, 25.7 \%, 20 \%$, and $8.6 \%$ post educational program and reached to $31.4 \%, 34.3 \%, 25.7 \%$, and $28.6 \%$ at 3 months post educational program, at pre educational program more than sixty $(65.7 \%)$ of head nurses had unsatisfactory level in the practice, decreased to $11.4 \%$ post educational program and reached to $37.1 \%$ at 3 month post educational program.

Figure (3): Shows mean percent of head nurses' meaningful recognition process knowledge pre, post and 3 month post educational program. As evidence in the figure, at pre educational program opportunities for growth and participation 
subscales of head nurses 'meaningful recognition process knowledge had the lowest mean percent (42.86\%) followed by over view of meaningful recognition process (34.63 \%), compensation (34.69\%)public acknowledgement (33.71\%), then private verbal feedback (30.42\%) and written acknowledgement had the lowest mean percent $(23.57 \%)$ respectively.

While, post educational program, opportunities for growth and participation and compensation subscales of head nurses 'meaningful recognition process knowledge had the highest mean percent (91.90\% and $91.02 \%)$ followed by over view of meaningful recognition process and private verbal feedback $(86.90 \%)$ and 88.07), then public acknowledgement $(85.43 \%)$ and written acknowledgement had the last mean percent $(84.52 \%)$ respectively. At 3 months post educational program,opportunities for growth and participation subscales of head nurses 'meaningful recognition process knowledge had the highest mean percent $(87.14 \%)$ followed by compensation $(85.71 \%)$ private verbal feedback (82.69\%), over view of meaningful recognition process $(81.95 \%)$, then public acknowledgement (80.86\%) and written acknowledgement had the lowest mean percent the lowest mean percent $(78.33 \%)$ respectively.

Table (3): Demonstrates the distribution of staff nurses' according to their demographic characteristics. It was observed that the majority $(78.0 \%)$ of staff nurses were female and married have 25 30 years old, working at general department, have 5- 10 years of experience and most of them $42.0 \%$ /have Institute of Technical level of education.

Figure (4): Shows distribution of staff nurses according to their overall satisfaction level of head nurses' practice of meaningful recognition process at pre and post educational program. It was observed that at pre educational program, the majority $(98.4 \%)$ of staff nurses had low level of satisfaction of head nurses' practice of meaningful recognition process, but decreased to few $(7.2 \%)$ post educational program, with significant difference at $\mathrm{p} \leq 0.05$

Table (4): Shows distribution of staff nurses according to their satisfaction level of head nurses' practice of meaningful recognition process at pre and post educational program. It was observed that at pre educational program, the majority ranged from $96.0 \%$ to $98.4 \%$ had low level 
of satisfaction in overall and all subscales of head nurses' practice of meaningful recognition process, but decreased to few percent ranged from $5.6 \%$ to $19.2 \%$ post educational program, with significant difference between pre and post educational program at $\mathrm{P}=<0.001$.

Figure (5): Describes mean percent levels of staff nurses ' satisfaction regarding head nurses' practice for meaningful recognition process pre and post educational program. At pre educational program the low mean percent of staff nurses ' satisfaction regarding head nurses' practice for meaningful recognition process ranged from $19.63 \%$ to $27.22 \%$ in all forms of meaningful recognition process with overall percent $23.45 \%$. But post educational program low mean percent of staff nurses ' satisfaction regarding head nurses' practice for meaningful recognition process improved to be ranged from $62.43 \%$ to $56.57 \%$ in all forms of meaningful recognition process with overall percent $60.29 \%$

Figure (6): Shows mean scores and mean percent of head nurses' practice of meaningful recognition process pre, post and 3 month post educational program. As shown in the table, there were significant improvements in overall mean score and mean percent of head nurses' practice of meaningful recognition process and its subscales at $\mathrm{P} \leq 0.05$ post educational program and at 3 month post educational program than pre educational program.

As evidence in the table at pre educational program the lowest mean percent $(42.45 \%)$ of head nurses' practice of meaningful recognition process was given to compensation subscale, followed by private verbal feedback subscale $(41.80 \%)$, public acknowledgement subscale $(30.77 \%)$, and opportunities for growth and participation subscale $27.36 \%$ respectively. While the lowest mean percent $(18.10 \%)$ of head nurses' practice of meaningful recognition process was given to written acknowledgement subscale.

While at post educational program the first mean percent $(79.05 \%)$ of head nurses practice of meaningful recognition process was given to written acknowledgement subscale, followed by private verbal feedback subscale, (74.14\%), compensation subscale $(73.67 \%)$, and then public acknowledgement subscale $(67.47 \%)$, and but the last mean percent $(67.14 \%)$ of head nurses practice of meaningful recognition process was given 
to opportunities for growth and participation subscale, respectively.

But at 3 months post educational program the highest mean percent $(62.86 \%)$ of head nurses' practice of meaningful recognition process was given to compensation subscale, followed by written acknowledgement subscale (59.76\%),opportunities for growth and participation subscale (57. $47 \%$ ), and public acknowledgement subscale (57.14\%), respectively. At the lowest mean percent $(56.69 \%)$ of head nurses' practice of meaningful recognition process was given to private verbal feedback subscale.

Figure (7): Represents the difference of head nurses' total level, mean score and mean percent of meaningful recognition process knowledge pre, post, and 3 months post educational program. It was observed that high percent $(77.1 \%)$ of head nurses had poor level of meaningful recognition knowledge at pre educational program, while at post educational program majority $(88.6 \%)$ of them had good level of meaningful recognition knowledge and 3 months post educational program. majority $(82.9 \%)$ of head nurses had good level of knowledge with significant difference between pre, post and 3 months post educational program at $\mathrm{p}=<0.001$.
Table (6): Demonstrates correlation between head nurse ' knowledge \&practice of meaningful recognition process at post educational program. Statistical significant positive correlation was found between head nurses' overall knowledge of meaningful recognition process, its items and their overall practice of meaningful recognition process and its subscales at $\mathrm{P}<$ 0.05

Table (7): Represents correlation between head nurses' practice of meaningful recognition process and staff nurses' satisfaction of meaningful recognition process at post educational program. It was found that, there were significant correlation between head nurses' overall practice of meaningful recognition process and its overall subscale with their staff nurses' overall satisfaction of head nurses' practice of meaningful recognition process and its overall subscale at $p \leq 0.05$. Private verbal feedback and compensation subscale of head nurses' practice of meaningful recognition process had significant positive correlation with all subscale of staff nurses' satisfaction of head nurses practice of meaningful recognition process at $\mathrm{p} \leq 0.05$.

Table (8): Demonstrates correlation between head nurses' knowledge of 
meaningful recognition process and staff nurses' satisfaction of head nurses' knowledge of meaningful recognition process at post educational program. Overall knowledge of head nurses' meaningful recognition process and its items had significant correlation with overall staff nurses' satisfaction and its items of meaningful recognition process except overall written acknowledgment of head nurses showed no significant correlation and also with all subscales of staff nurses satisfaction at $\mathrm{p} \leq 0.05$. 
Table (1): Distribution of head nurses according to their characteristics $(n=35)$

\begin{tabular}{|c|c|c|}
\hline Head nurses' characteristics & No. & $\%$ \\
\hline \multicolumn{3}{|l|}{ Age (years) } \\
\hline$<40$ & 16 & 45.7 \\
\hline $40-50$ & 13 & 37.1 \\
\hline$\geq 50$ & 6 & 17.1 \\
\hline Min. - Max. & \multirow{2}{*}{\multicolumn{2}{|c|}{$\begin{array}{c}35.0-55.0 \\
42.31 \pm 6.21\end{array}$}} \\
\hline Mean \pm SD & & \\
\hline \multicolumn{3}{|l|}{ Marital status } \\
\hline Single & 2 & 5.7 \\
\hline Married & 28 & 80.0 \\
\hline Divorced & 1 & 2.9 \\
\hline Widow & 4 & 11.4 \\
\hline \multicolumn{3}{|l|}{ Years of experience (years) } \\
\hline$<15$ & 6 & 17.1 \\
\hline $15-25$ & 22 & 62.9 \\
\hline$\geq 25$ & 7 & 20.0 \\
\hline Min. - Max. & \multirow{2}{*}{\multicolumn{2}{|c|}{$\begin{array}{c}13.0-33.0 \\
20.31 \pm 6.21\end{array}$}} \\
\hline Mean \pm SD & & \\
\hline \multicolumn{3}{|l|}{ Educational level } \\
\hline Baccalaureate degree in nursing & 26 & 74.3 \\
\hline Master degree in nursing & 2 & 5.7 \\
\hline Doctorial degree in nursing & 1 & 2.9 \\
\hline Diploma in nursing & 6 & 17.1 \\
\hline \multicolumn{3}{|l|}{ Department } \\
\hline Special unit & 13 & 37.1 \\
\hline General unit & 19 & 45.3 \\
\hline Others & 3 & 8.6 \\
\hline
\end{tabular}

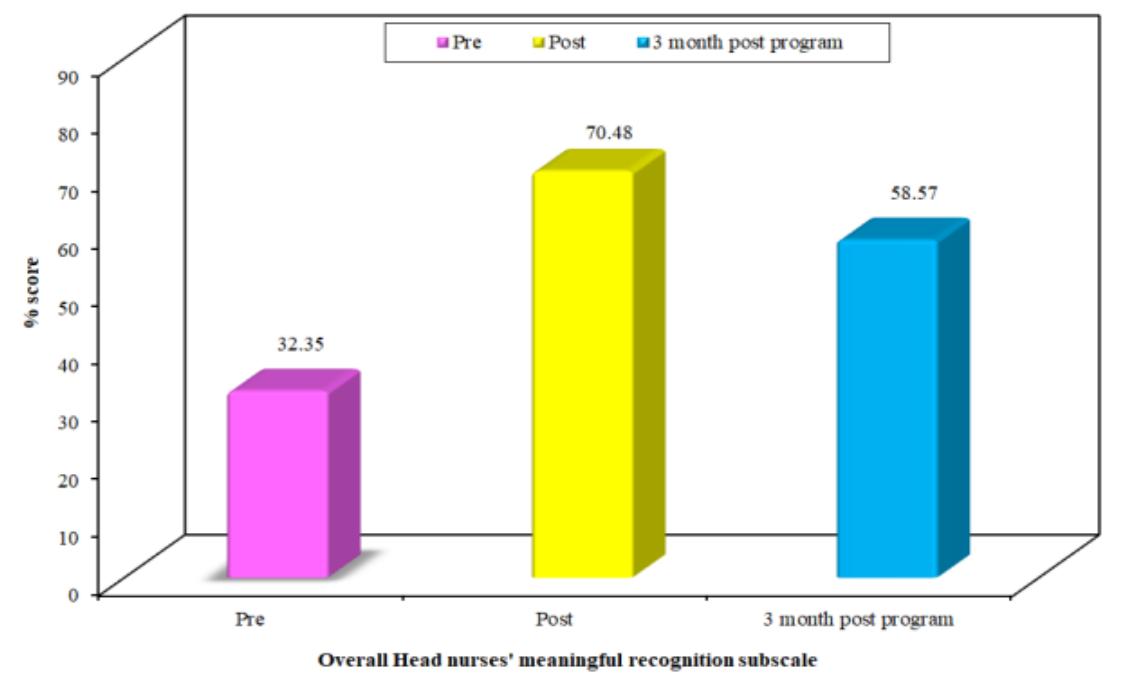

Fig. (2): Overall head nurses' practice of meaningful recognition subscale. 
Table (2): Difference of head nurses' practice levels of meaningful recognition process at pre, post, and at 3 months post educational program(n $=35$ )

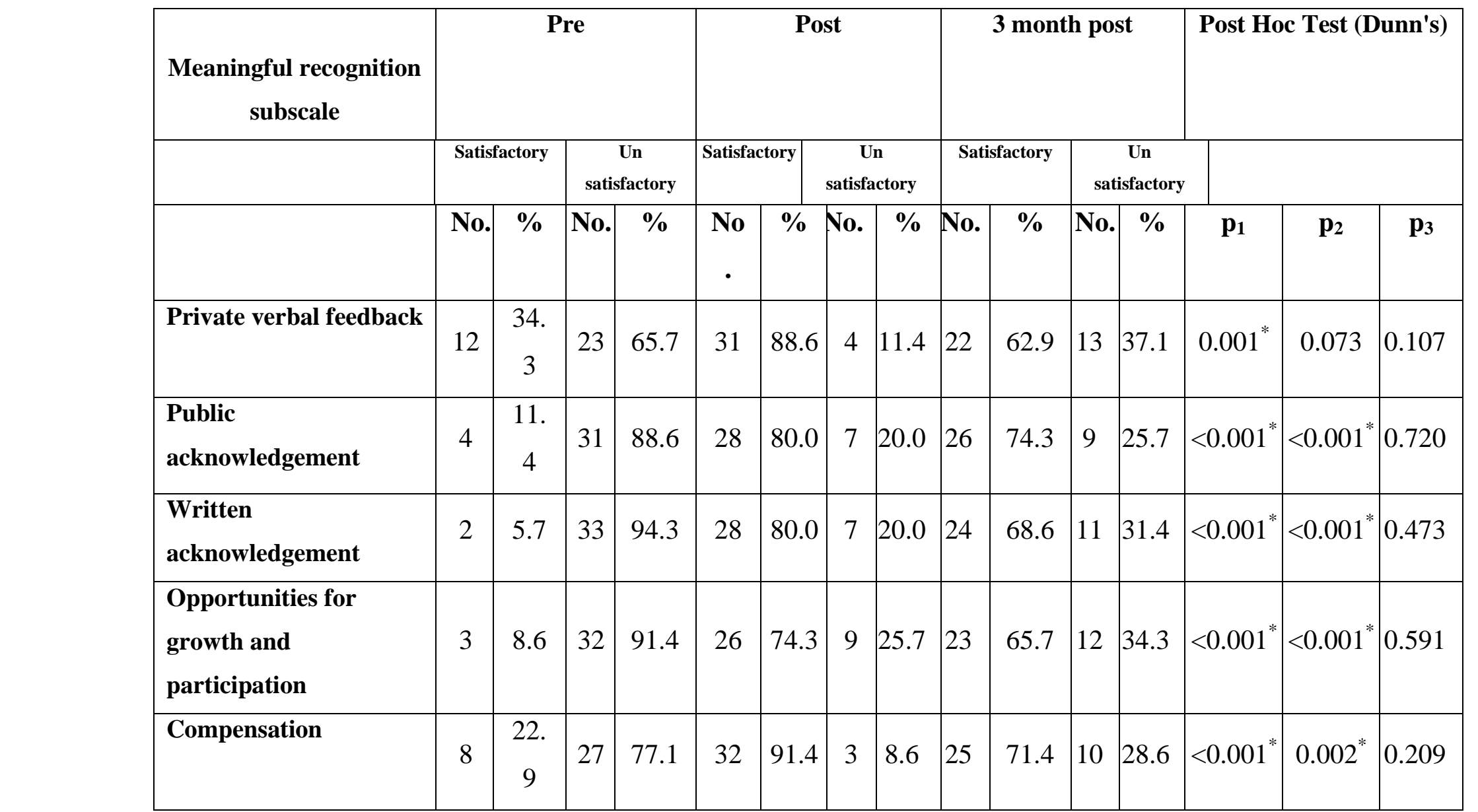

*: Statistically significant at $\mathrm{p} \leq 0.001$

Vol. 21 No. 2 May, 2021 


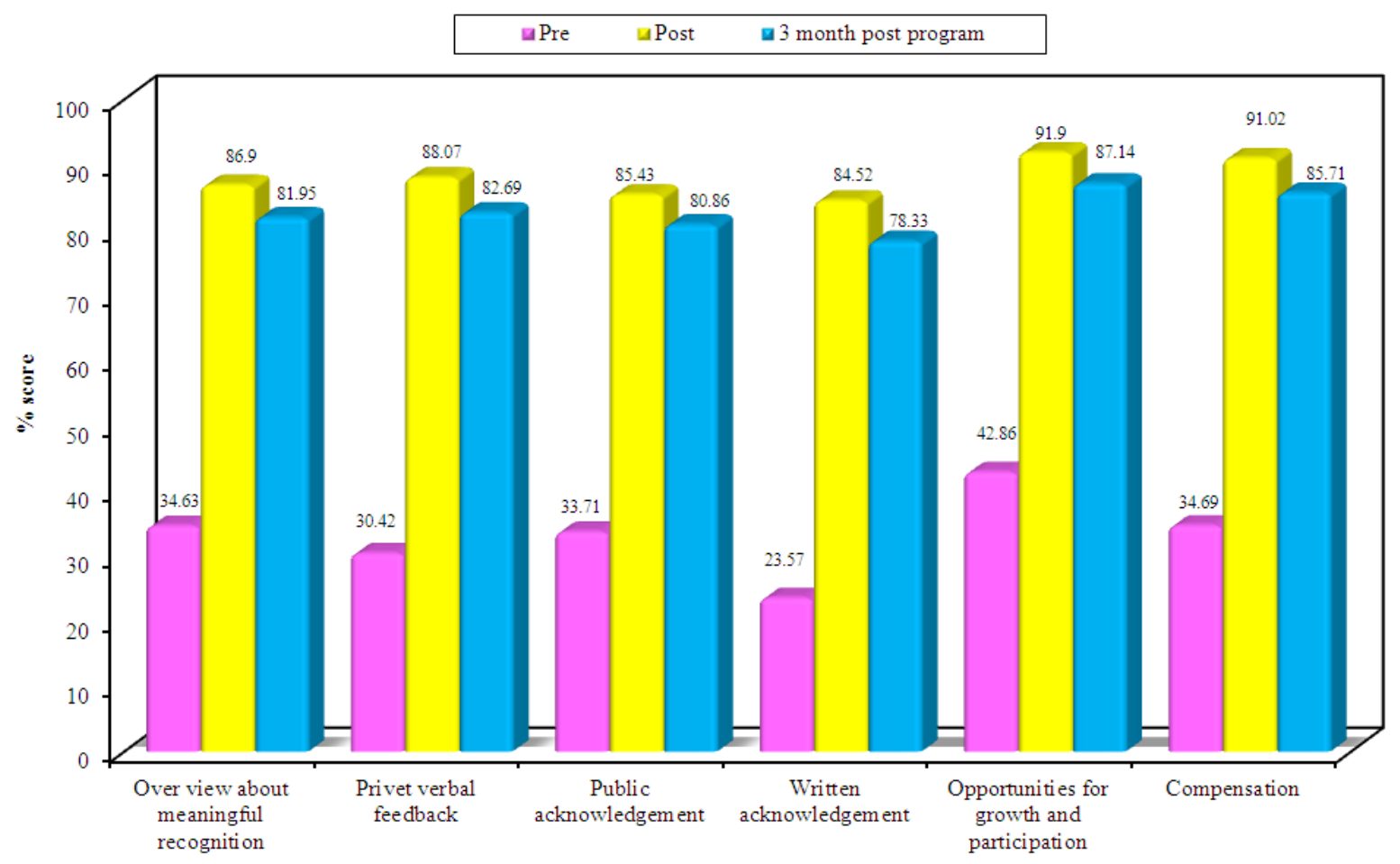

Head nurses mean score according to their knowledgeabout meaningful recognition

Figure (3):Mean percent of head nurses' meaningful recognition process knowledge pre, post and 3 month post educational program $(n=35)$ 
Table (3): Distribution of staff nurses' according to their demographic characteristic $(n=250)$

\begin{tabular}{|c|c|c|}
\hline Staff nurses characteristics & No. & $\%$ \\
\hline \multicolumn{3}{|l|}{ Age (years) } \\
\hline$<25$ & 102 & 40.8 \\
\hline $25-30$ & 121 & 48.4 \\
\hline$\geq 35$ & 27 & 10.8 \\
\hline Min. - Max. & \multirow{2}{*}{\multicolumn{2}{|c|}{$\begin{array}{c}23.0-39.0 \\
26.42 \pm 4.09\end{array}$}} \\
\hline Mean \pm SD & & \\
\hline \multicolumn{3}{|l|}{ Gender } \\
\hline Male & 55 & 22.0 \\
\hline Female & 195 & 78.0 \\
\hline \multicolumn{3}{|l|}{ Marital status } \\
\hline Single & 54 & 21.6 \\
\hline Married & 196 & 78.4 \\
\hline \multicolumn{3}{|l|}{ Years of experience (years) } \\
\hline$<5$ & 107 & 42.8 \\
\hline $5-10$ & 117 & 46.8 \\
\hline$\geq 10$ & 26 & 10.4 \\
\hline Min. - Max. & \multirow{2}{*}{\multicolumn{2}{|c|}{$\begin{array}{c}2.0-18.0 \\
5.39 \pm 3.21\end{array}$}} \\
\hline Mean \pm SD & & \\
\hline \multicolumn{3}{|l|}{ Educational level } \\
\hline Baccalaureate Degree in Nursing & 58 & 23.2 \\
\hline Institute of technical in nursing & 105 & 42.0 \\
\hline Associate Degree in Nursing & 87 & 34.8 \\
\hline \multicolumn{3}{|l|}{ Department } \\
\hline General department & 76 & 30.4 \\
\hline Special department & 174 & 69.6 \\
\hline
\end{tabular}




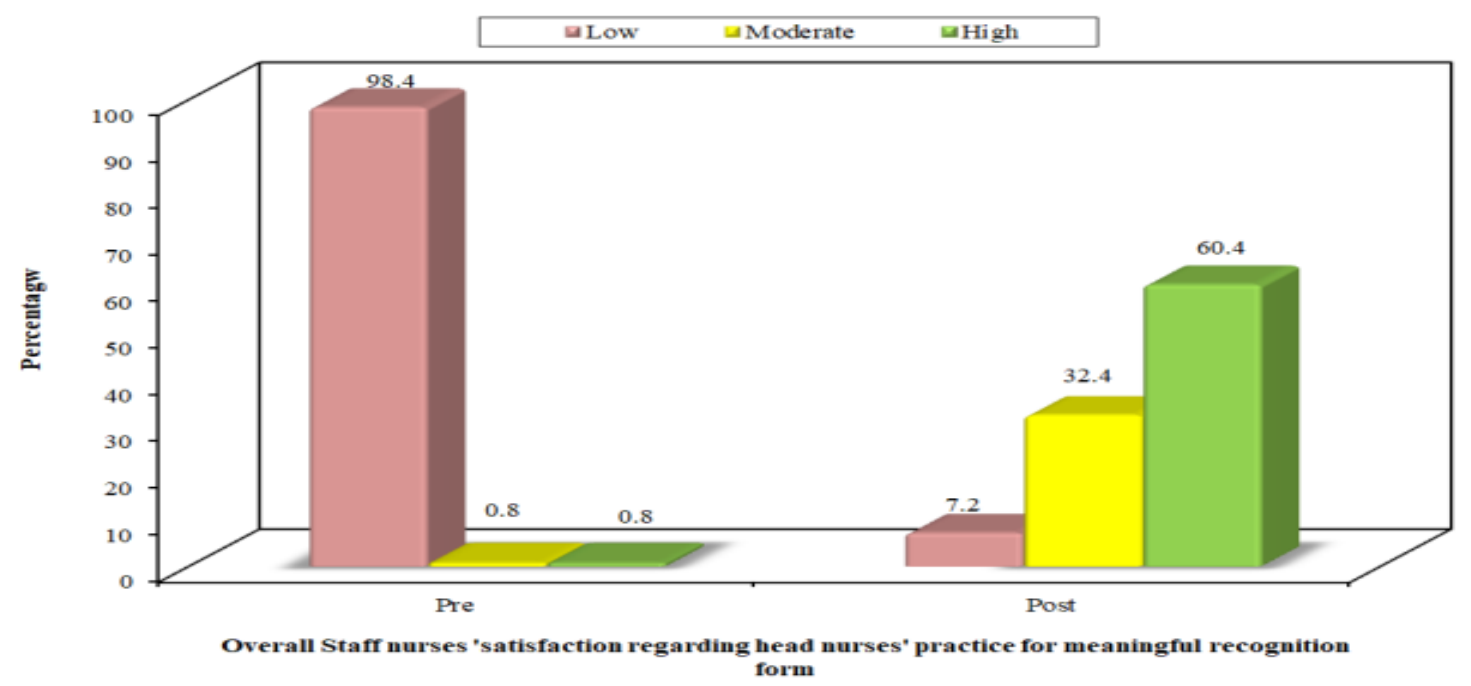

Figure (4): Distribution of staff nurses according to their overall satisfaction level of head nurses' practice of meaningful recognition process at pre and post educational intervention

Table (4): Distribution of staff nurses according to their satisfaction level of head nurses' practice of meaningful recognition process at pre and post educational intervention $(\mathbf{n}=\mathbf{2 5 0})$

\begin{tabular}{|c|c|c|c|c|c|c|c|c|c|c|c|c|c|}
\hline \multirow{3}{*}{$\begin{array}{l}\text { Head nurses' practice } \\
\text { of meaningful } \\
\text { recognition process }\end{array}$} & \multicolumn{6}{|c|}{ Pre } & \multicolumn{6}{|c|}{ Post } & \multirow{3}{*}{$\mathbf{p}$} \\
\hline & \multicolumn{2}{|c|}{ Low } & \multicolumn{2}{|c|}{ Moderate } & \multicolumn{2}{|c|}{ High } & \multicolumn{2}{|c|}{ Low } & \multicolumn{2}{|c|}{ Moderate } & \multicolumn{2}{|c|}{ High } & \\
\hline & No. & $\%$ & No. & $\%$ & No. & $\%$ & No. & $\%$ & No. & $\%$ & No. & $\%$ & \\
\hline Private verbal feedback & 244 & 97.6 & 4 & 1.6 & 2 & 0.8 & 20 & 8.0 & 58 & 23.2 & 172 & 68.8 & $<0.001{ }^{*}$ \\
\hline $\begin{array}{c}\text { Public } \\
\text { acknowledgement }\end{array}$ & 240 & 96.0 & 8 & 3.2 & 2 & 0.8 & 22 & 8.8 & 68 & 27.2 & 160 & 64.0 & $<0.001^{*}$ \\
\hline $\begin{array}{c}\text { Written } \\
\text { acknowledgement }\end{array}$ & 244 & 97.6 & 4 & 1.6 & 2 & 0.8 & 37 & 14.8 & 60 & 24.0 & 153 & 61.2 & $<0.001^{*}$ \\
\hline $\begin{array}{l}\text { Opportunities for } \\
\text { growth and } \\
\text { participation }\end{array}$ & 246 & 98.4 & 2 & 0.8 & 2 & 0.8 & 14 & 5.6 & 88 & 35.2 & 148 & 59.2 & $<0.001^{*}$ \\
\hline Compensation & 242 & 96.8 & 4 & 1.6 & 4 & 1.6 & 48 & 19.2 & 78 & 31.2 & 124 & 49.6 & $<0.001{ }^{*}$ \\
\hline
\end{tabular}

*: Statistically significant at $\mathrm{p} \leq 0.05$ 


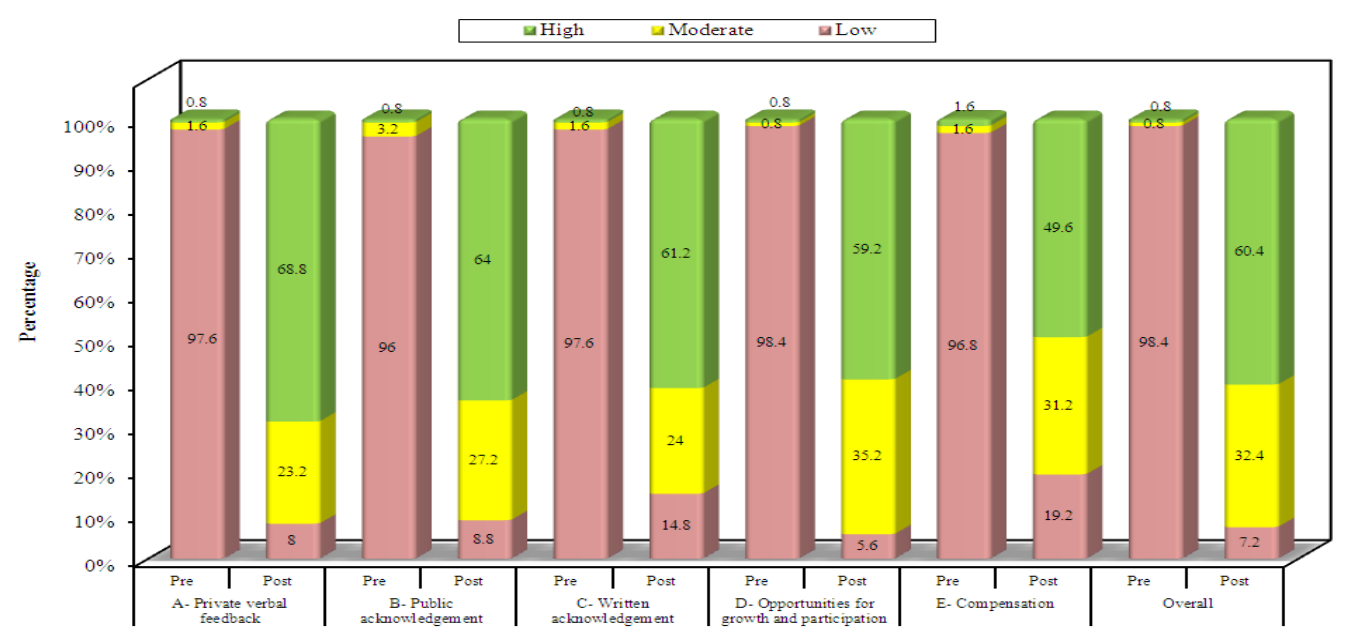

Figure (5): Mean percent levels of staff nurses ' satisfaction regarding head nurses' practice for meaningful recognition process pre and post educational program $(\mathbf{n}=\mathbf{2 5 0})$.

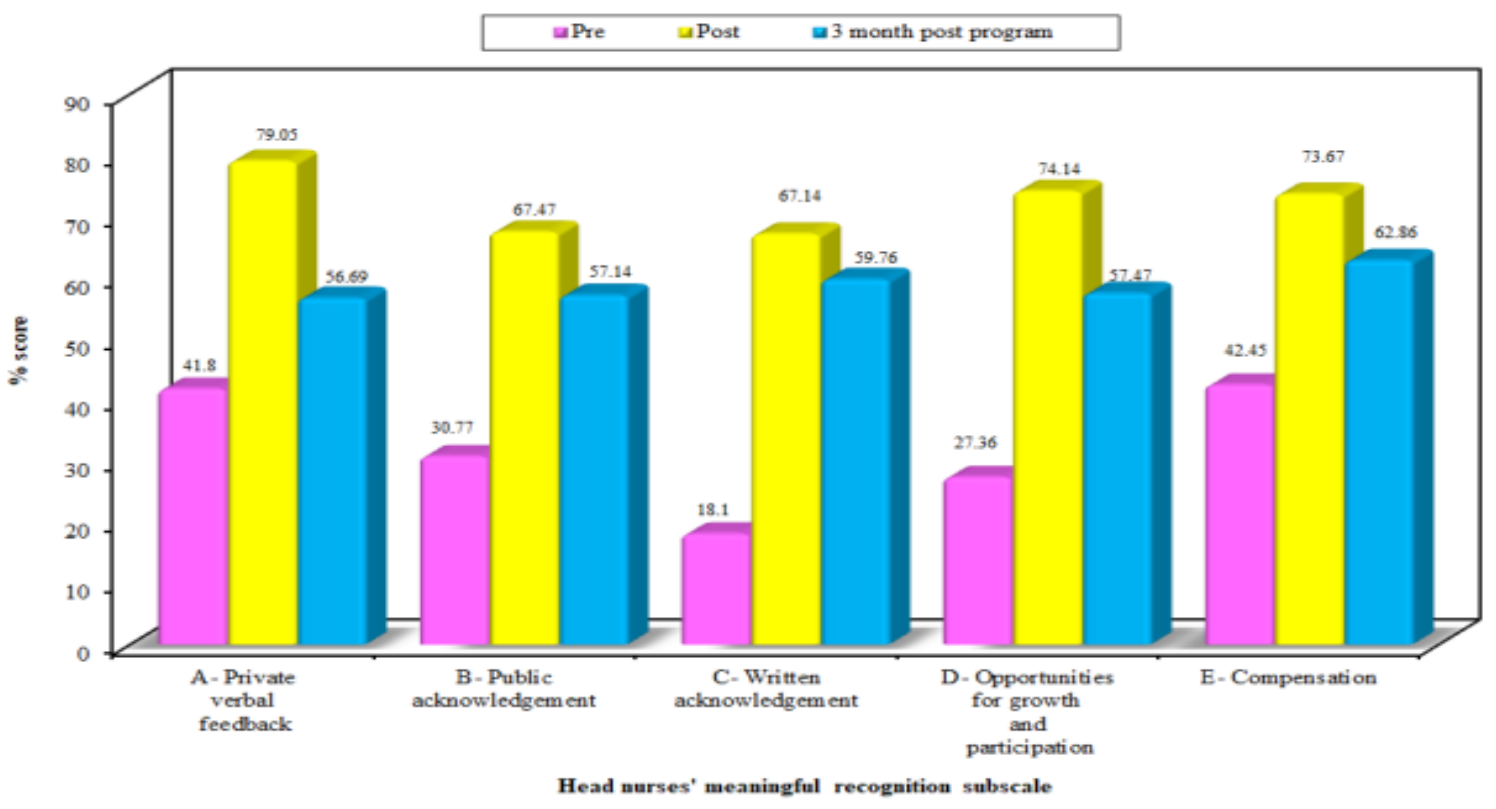

Figure (6): Mean percent of head nurses' practice of meaningful recognition process pre, post and 3 month post educational program $(n=35)$ 


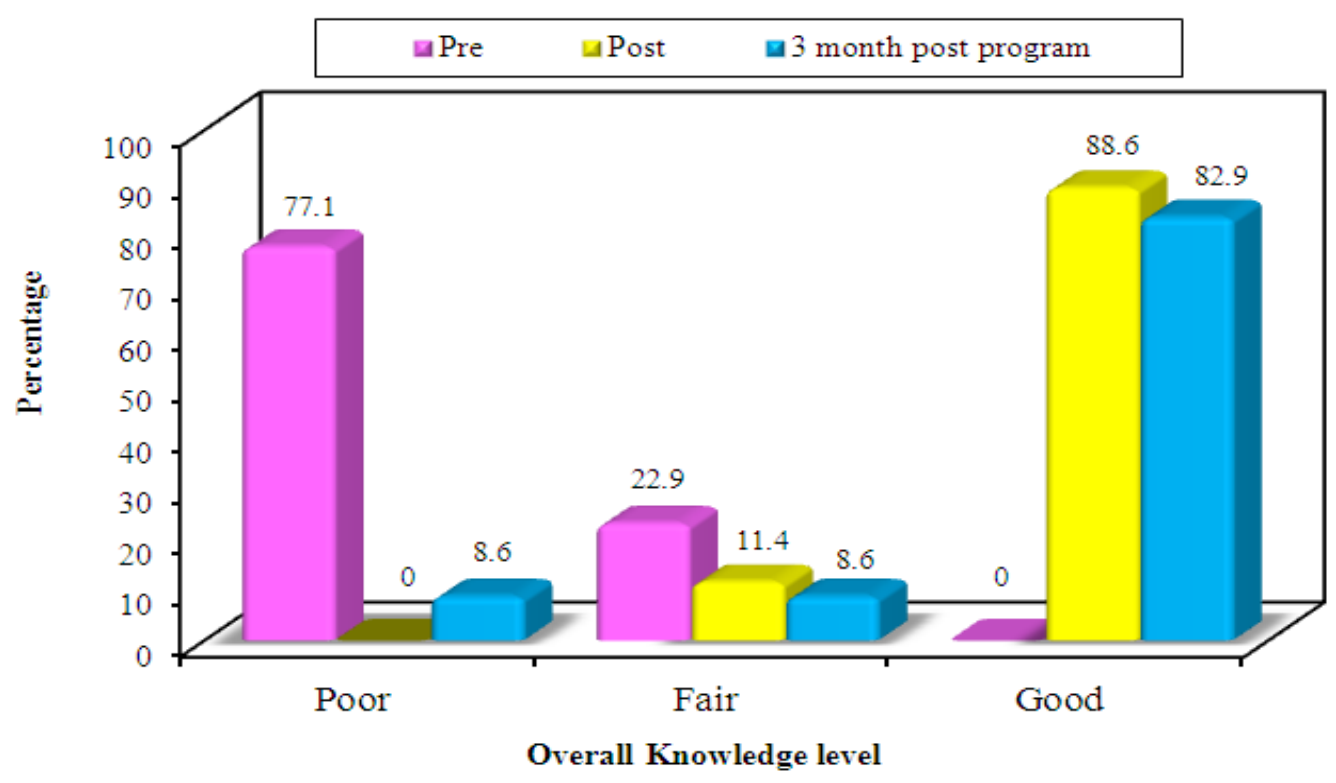

Figure (7): displays the difference of head nurses total level about meaningful recognition process knowledge pre, post, and 3 months post educational program. 
Table (5): Distribution of head nurses according to their level of meaningful recognition process knowledge at pre, post, and at 3 months post educational program $(n=35)$

\begin{tabular}{|c|c|c|c|c|c|c|c|c|c|c|c|c|c|c|c|c|c|c|c|}
\hline \multirow{3}{*}{$\begin{array}{c}\text { Head nurses' meaningful } \\
\text { recognition process } \\
\text { knowledge. }\end{array}$} & \multicolumn{6}{|c|}{ Pre } & \multicolumn{6}{|c|}{ Post } & \multicolumn{6}{|c|}{3 months post program } & \multirow{3}{*}{$\begin{array}{c}\mathbf{p}_{1}, 2 \& \& \\
p_{3}\end{array}$} \\
\hline & \multicolumn{2}{|c|}{ Poor } & \multicolumn{2}{|c|}{ Fair } & \multicolumn{2}{|c|}{ Good } & \multicolumn{2}{|c|}{ Poor } & \multicolumn{2}{|c|}{ Fair } & \multicolumn{2}{|c|}{ Good } & \multicolumn{2}{|c|}{ Poor } & \multicolumn{2}{|c|}{ Fair } & \multicolumn{2}{|c|}{ Good } & \\
\hline & No. & $\%$ & No. & $\%$ & No. & $\%$ & No. & $\%$ & No. & $\%$ & No. & $\%$ & No. & $\%$ & No. & $\%$ & No. & $\%$ & \\
\hline $\begin{array}{l}\text { over view about } \\
\text { meaningful recognition }\end{array}$ & 27 & 77.1 & 7 & 20.0 & 1 & 2.9 & 0 & 0.0 & 5 & 14.3 & 30 & 85.7 & 3 & 8.6 & 6 & 17.1 & 26 & 74.3 & $\begin{array}{l}<0.001^{*} \\
0.310\end{array}$ \\
\hline Privet verbal feedback & 29 & 82.9 & 6 & 17.1 & 0 & 0.0 & 0 & 0.0 & 2 & 5.7 & 33 & 94.3 & 3 & 8.6 & 5 & 14.3 & 27 & 77.1 & $\begin{array}{r}<0.001^{*} \\
0.310\end{array}$ \\
\hline Public acknowledgement & 32 & 91.4 & 3 & 8.6 & 0 & 0.0 & 0 & 0.0 & 7 & 20.0 & 28 & 80.0 & 4 & 11.4 & 6 & 17.1 & 25 & 71.4 & $\begin{array}{l}<0.001^{*} \\
0.339\end{array}$ \\
\hline $\begin{array}{l}\text { Written } \\
\text { acknowledgement }\end{array}$ & 33 & 94.3 & 2 & 5.7 & 0 & 0.0 & 3 & 8.6 & 7 & 20.0 & 25 & 71.4 & 5 & 14.3 & 4 & 11.4 & 26 & 74.3 & $\begin{array}{l}<0.001^{*} \\
0.811\end{array}$ \\
\hline $\begin{array}{l}\text { opportunities for growth } \\
\text { and participation }\end{array}$ & 24 & 68.6 & 11 & 31.4 & 0 & 0.0 & 0 & 0.0 & 1 & 2.9 & 34 & 97.1 & 3 & 8.6 & 1 & 2.9 & 31 & 88.6 & $\begin{array}{l}<0.001^{*} \\
0.591\end{array}$ \\
\hline Compensation & 23 & 65.7 & 9 & 25.7 & 3 & 8.6 & 0 & 0.0 & 6 & 17.1 & 29 & 82.9 & 4 & 11.4 & 5 & 14.3 & 26 & 74.3 & $\begin{array}{l}<0.001 \\
0.209\end{array}$ \\
\hline
\end{tabular}

*: Statistically significant at $\mathrm{p} \leq 0.05$

Vol. 21 No. 2 May, 2021 
Table (6): Correlation between head nurse ' knowledge \&practice of meaningful recognition process at post program $(\mathrm{n}=35)$

\begin{tabular}{|c|c|c|c|c|c|c|c|}
\hline \multirow[b]{2}{*}{$\begin{array}{c}\text { Head nurses' knowledge of } \\
\text { meaningful recognition } \\
\text { process }\end{array}$} & & \multicolumn{6}{|c|}{ Head nurses' practice of meaningful recognition process } \\
\hline & & $\begin{array}{l}\text { Private verbal } \\
\text { feedback }\end{array}$ & \begin{tabular}{|c|} 
Public \\
acknowledgeme \\
nt
\end{tabular} & $\begin{array}{c}\text { Written } \\
\text { acknowledgeme } \\
\text { nt }\end{array}$ & $\begin{array}{c}\text { Opportunities } \\
\text { for growth and } \\
\text { participation }\end{array}$ & Compensation & Overall \\
\hline $\begin{array}{l}\text { Over view about meaningful } \\
\text { recognition }\end{array}$ & $\begin{array}{l}\mathbf{r} \\
\mathbf{p}\end{array}$ & $\begin{array}{l}0.760^{*} \\
<0.001^{*}\end{array}$ & \begin{tabular}{|c|}
$0.687^{*}$ \\
$<0.001^{*}$ \\
\end{tabular} & $\begin{array}{l}0.461^{*} \\
0.005^{*} \\
\end{array}$ & $\begin{array}{c}0.675^{*} \\
<0.001^{*} \\
\end{array}$ & $\begin{array}{l}0.821^{*} \\
<0.001^{*}\end{array}$ & $\begin{array}{l}0.772^{*} \\
<0.001^{*}\end{array}$ \\
\hline Privet verbal feedback & $\mathbf{r}$ & $\begin{array}{l}0.650^{*} \\
<0.001^{*}\end{array}$ & $\begin{array}{l}0.504^{*} \\
0.002^{*}\end{array}$ & $\begin{array}{l}0.259 \\
0.133\end{array}$ & $\begin{array}{l}0.489^{*} \\
0.003^{*}\end{array}$ & $\begin{array}{l}0.689^{*} \\
<0.001^{*}\end{array}$ & $\begin{array}{l}0.596^{*} \\
<0.001^{*}\end{array}$ \\
\hline Public acknowledgement & $\mathbf{r}$ & $\begin{array}{l}0.368^{*} \\
0.029^{*}\end{array}$ & $\begin{array}{l}0.390^{*} \\
0.021^{*}\end{array}$ & $\begin{array}{l}0.257 \\
0.136\end{array}$ & $\begin{array}{l}0.406^{*} \\
0.015^{*}\end{array}$ & $\begin{array}{l}0.331 \\
0.052\end{array}$ & $\begin{array}{l}0.403^{*} \\
0.016^{*}\end{array}$ \\
\hline Written acknowledgement & $\mathbf{r}$ & $\begin{array}{l}0.835^{*} \\
<0.001^{*}\end{array}$ & $\begin{array}{l}0.699^{*} \\
<0.001^{*}\end{array}$ & $\begin{array}{l}0.489^{*} \\
0.003^{*}\end{array}$ & $\begin{array}{l}0.691^{*} \\
<0.001^{*}\end{array}$ & $\begin{array}{l}0.859^{*} \\
<0.001^{*}\end{array}$ & $\begin{array}{l}0.812^{*} \\
<0.001^{*}\end{array}$ \\
\hline $\begin{array}{l}\text { opportunities for growth and } \\
\text { participation }\end{array}$ & $\begin{array}{l}\mathbf{r} \\
\mathbf{p}\end{array}$ & $\begin{array}{l}0.603^{*} \\
<0.001^{*}\end{array}$ & $\begin{array}{l}0.527^{*} \\
0.001^{*}\end{array}$ & $\begin{array}{l}0.265 \\
0.123\end{array}$ & $\begin{array}{l}0.480^{*} \\
0.003^{*}\end{array}$ & $\begin{array}{c}0.587^{*} \\
<0.001^{*}\end{array}$ & $\begin{array}{l}0.566^{*} \\
<0.001^{*}\end{array}$ \\
\hline Compensation & $\begin{array}{l}\mathbf{r} \\
\mathbf{p}\end{array}$ & $\begin{array}{c}0.749^{*} \\
<0.001^{*}\end{array}$ & $\begin{array}{l}0.588^{*} \\
<0.001^{*}\end{array}$ & $\begin{array}{l}0.363^{*} \\
0.032^{*}\end{array}$ & $\begin{array}{l}0.613^{*} \\
<0.001^{*}\end{array}$ & $\begin{array}{c}0.691^{*} \\
<0.001^{*}\end{array}$ & $\begin{array}{l}0.695^{*} \\
<0.001^{*}\end{array}$ \\
\hline Overall & $\begin{array}{l}\mathbf{r} \\
\mathbf{p}\end{array}$ & $\begin{array}{c}0.790^{*} \\
<0.001^{*}\end{array}$ & $\begin{array}{c}0.682^{*} \\
<0.001^{*}\end{array}$ & $\begin{array}{l}0.428^{*} \\
0.010^{*}\end{array}$ & $\begin{array}{c}0.670^{*} \\
<0.001^{*}\end{array}$ & $\begin{array}{c}0.816^{*} \\
<0.001^{*}\end{array}$ & $\begin{array}{c}0.773^{*} \\
<0.001^{*}\end{array}$ \\
\hline
\end{tabular}

*: Statistically significant at $\mathrm{p} \leq 0.05$ 
Table (7): Correlation between head nurses' practice of meaningful recognition process and staff nurses' satisfaction of meaningful recognition process at post educational program.

\begin{tabular}{|c|c|c|c|c|c|c|c|}
\hline \multirow{2}{*}{\multicolumn{2}{|c|}{$\begin{array}{c}\text { Head nurses' } \\
\text { practice of } \\
\text { meaningful } \\
\text { recognition }\end{array}$}} & \multicolumn{6}{|c|}{ Staff nurses' satisfaction of meaningful recognition process } \\
\hline & & $\begin{array}{c}\text { Private } \\
\text { verbal } \\
\text { feedback }\end{array}$ & $\begin{array}{c}\text { Public } \\
\text { acknowledge } \\
\text { ment }\end{array}$ & $\begin{array}{c}\text { Written } \\
\text { acknowledge } \\
\text { ment }\end{array}$ & $\begin{array}{c}\text { Opportunities for } \\
\text { growth and } \\
\text { participation }\end{array}$ & Compensation & Overall \\
\hline $\begin{array}{l}\text { Private verbal } \\
\text { feedback }\end{array}$ & $\mathbf{r}$ & $\begin{array}{l}0.206^{*} \\
0.001^{*}\end{array}$ & $\begin{array}{l}0.238^{*} \\
<0.001^{*}\end{array}$ & $\begin{array}{l}0.132^{*} \\
0.036^{*}\end{array}$ & $\begin{array}{l}0.174^{*} \\
0.006^{*}\end{array}$ & $\begin{array}{l}0.343^{*} \\
0.044^{*}\end{array}$ & $\begin{array}{l}0.147^{*} \\
0.020^{*}\end{array}$ \\
\hline $\begin{array}{l}\text { Public } \\
\text { acknowledgement }\end{array}$ & $\mathbf{p}$ & $\begin{array}{l}0.114 \\
0.073\end{array}$ & $\begin{array}{l}0.151^{*} \\
0.017^{*}\end{array}$ & $\begin{array}{l}0.028 \\
0.663\end{array}$ & $\begin{array}{l}0.091 \\
0.151\end{array}$ & $\begin{array}{l}-0.074 \\
0.244\end{array}$ & $\begin{array}{l}0.207^{*} \\
0.001^{*}\end{array}$ \\
\hline $\begin{array}{l}\text { Written } \\
\text { acknowledgement }\end{array}$ & $\begin{array}{l}\mathbf{r} \\
\mathbf{p}\end{array}$ & $\begin{array}{l}-0.211^{*} \\
0.001^{*}\end{array}$ & $\begin{array}{l}-0.265^{*} \\
<0.001^{*}\end{array}$ & $\begin{array}{l}-0.133^{*} \\
0.036^{*}\end{array}$ & $\begin{array}{l}-0.108 \\
0.090\end{array}$ & $\begin{array}{l}-0.065 \\
0.305\end{array}$ & $\begin{array}{l}-0.139^{*} \\
0.028^{*}\end{array}$ \\
\hline $\begin{array}{l}\text { Opportunities for } \\
\text { growth and } \\
\text { participation }\end{array}$ & $\mathbf{p}$ & $\begin{array}{l}0.079 \\
0.215\end{array}$ & $\begin{array}{l}0.132^{*} \\
0.038^{*}\end{array}$ & $\begin{array}{l}0.097 \\
0.125\end{array}$ & $\begin{array}{l}0.086 \\
0.174\end{array}$ & $\begin{array}{l}0.282^{*} \\
<0.001^{*}\end{array}$ & $\begin{array}{l}-0.139^{*} \\
0.028^{*}\end{array}$ \\
\hline Compensation & $\mathbf{r}$ & $\begin{array}{l}0.207^{*} \\
0.001^{*}\end{array}$ & $\begin{array}{l}0.298^{*} \\
<0.001^{*}\end{array}$ & $\begin{array}{l}0.268^{*} \\
<0.001^{*}\end{array}$ & $\begin{array}{l}0.205^{*} \\
0.001^{*}\end{array}$ & $\begin{array}{l}0.198^{*} \\
0.002^{*}\end{array}$ & $\begin{array}{l}0.257^{*} \\
<0.001^{*}\end{array}$ \\
\hline Overall & $\begin{array}{l}\mathbf{r} \\
\mathbf{p}\end{array}$ & $\begin{array}{l}0.231^{*} \\
<0.001^{*}\end{array}$ & $\begin{array}{l}0.129^{*} \\
0.041^{*}\end{array}$ & $\begin{array}{l}0.163^{*} \\
0.010^{*}\end{array}$ & $\begin{array}{l}0.146^{*} \\
0.021^{*}\end{array}$ & $\begin{array}{l}0.164^{*} \\
0.009^{*}\end{array}$ & $\begin{array}{l}0.185^{*} \\
0.003^{*}\end{array}$ \\
\hline
\end{tabular}

*: Statistically significant at $\mathrm{p} \leq 0.05$ 
Table (8): Correlation between head nurse's knowledge of meaningful recognition process and staff nurses' satisfaction of head nurse's knowledge of meaningful recognition process at post educational program.

\begin{tabular}{|c|c|c|c|c|c|c|c|}
\hline \multirow{2}{*}{\multicolumn{2}{|c|}{$\begin{array}{l}\text { Head nurses' knowledge } \\
\text { meaningful recognition process }\end{array}$}} & \multicolumn{6}{|c|}{ Staff nurses' satisfaction regarding meaningful recognition process } \\
\hline & & $\begin{array}{c}\text { Private } \\
\text { verbal } \\
\text { feedback } \\
\end{array}$ & $\begin{array}{c}\text { Public } \\
\text { acknowledg } \\
\text { ment }\end{array}$ & $\begin{array}{c}\text { Written } \\
\text { acknowledge } \\
\text { ment } \\
\end{array}$ & $\begin{array}{c}\text { Opportunities for } \\
\text { growth and } \\
\text { participation }\end{array}$ & Compensation & Overall \\
\hline over view of meaningful & $\mathbf{r}$ & $0.369^{*}$ & $0.368^{*}$ & $0.445^{*}$ & 0.298 & $0.424^{*}$ & $0.416^{*}$ \\
\hline recognition & $\mathbf{p}$ & $0.029^{*}$ & $0.030^{*}$ & $0.007^{*}$ & 0.082 & $0.011^{*}$ & $0.013^{*}$ \\
\hline \multirow{2}{*}{ Privet verbal feedback } & $\mathbf{r}$ & $0.406^{*}$ & $0.358^{*}$ & 0.313 & $0.478^{*}$ & 0.267 & $0.343^{*}$ \\
\hline & $\mathbf{p}$ & $0.015^{*}$ & $0.035^{*}$ & 0.067 & $0.004^{*}$ & 0.121 & $0.044^{*}$ \\
\hline \multirow{2}{*}{ Public acknowledgement } & $\mathbf{r}$ & 0.318 & $0.395^{*}$ & $0.438^{*}$ & $0.381^{*}$ & 0.265 & 0.318 \\
\hline & p & 0.063 & $0.019^{*}$ & $0.009^{*}$ & $0.024^{*}$ & 0.125 & 0.063 \\
\hline \multirow{2}{*}{ Written acknowledgement } & $\mathbf{r}$ & 0.185 & 0.252 & 0.320 & 0.256 & 0.246 & 0.265 \\
\hline & p & 0.288 & 0.144 & 0.061 & 0.137 & 0.154 & 0.124 \\
\hline \multirow{2}{*}{$\begin{array}{l}\text { opportunities for growth } \\
\text { and participation }\end{array}$} & $\mathbf{r}$ & -0.101 & -0.078 & 0.182 & 0.154 & 0.155 & $0.421^{*}$ \\
\hline & p & 0.563 & 0.657 & 0.294 & 0.377 & 0.374 & $0.012^{*}$ \\
\hline \multirow{2}{*}{ Compensation } & $\mathbf{r}$ & $0.379^{*}$ & $0.373^{*}$ & $0.376^{*}$ & 0.267 & 0.188 & $0.398^{*}$ \\
\hline & p & $0.025^{*}$ & $0.027^{*}$ & $0.026^{*}$ & 0.120 & 0.278 & $0.018^{*}$ \\
\hline \multirow{2}{*}{ Overall } & $\mathbf{r}$ & $0.385^{*}$ & $0.406^{*}$ & $0.488^{*}$ & $0.409^{*}$ & $0.398^{*}$ & $0.435^{*}$ \\
\hline & p & $0.022^{*}$ & $0.015^{*}$ & $0.003^{*}$ & $0.015^{*}$ & $0.018^{*}$ & $0.009^{*}$ \\
\hline
\end{tabular}

*: Statistically significant at $\mathrm{p} \leq 0.05$ 


\section{Discussion}

At pre educational intervention, the results of the present study showed that the majority of head nurses had total unsatisfactory level of meaningful recognition practice with low mean percent. This is due to the majority of them had poor level of total knowledge about meaningful recognition and overview item with low mean percent. In addition, this result may be attributed to head nurses not believed in giving recognition to staff nurses as a result of fear of losing control, resistance apply democratic relationships, lack of time, and lack of knowledge and skill regarding implementation of meaningful recognition Brun \& Dugas (2002). ${ }^{(19)}$ So, the majority of staff nurses had low total satisfaction level regarding head nurses' meaningful recognition practice.

In this regard, Cherian (2016) ${ }^{(20)}$ reported that a lack of awareness about the concept of meaningful recognition and unavailability of best practices to provide meaningful recognition were the major reasons cited by staff nurses and nurse leaders for not providing meaningful recognition. In addition, limited resources, institutional policies and the size and diversity of the nursing workforce were also barriers to providing meaningful recognition.
This result reflects that head nurses are in need for education program to increase knowledge and skills for implementing meaningful recognition. El-demerdash (2006) ${ }^{(16)}$ mentioned that nurse managers have to be sensitive to staff nurses' recognition needs she also, revealed that over fifty percent of staff nurses perceived their nursing managers' poor in offering sincere positive recognition for staff nurses. Saunderson (2004) (21) emphasized that leaders and managers require much more training and educational resources to become more effective recognition givers.

In this respect, Zakzouk (2019) $)^{(22)}$ showed that high percent of staff nurses had low level of satisfaction about contingent rewards including appreciation, recognition and rewards for good work done. Elsayad (2016) ${ }^{(23)}$ revealed that high percent of staff nurses experienced low level of satisfaction about contingent rewards including appreciation, recognition, and rewards for good work achieved. Also, Asegid et al (2014) ${ }^{(24)}$ found that more than two fifths of study participants were dissatisfied with the level of recognition given to their work.

Abo-Gad\& Elkazeh (2013) ${ }^{(25)}$ found that the majority of emergency hospital nurse and high percent of community health nurse were dissatisfied of the contingent 
rewards. Rouse and AL-maqbali (2014) ${ }^{(26)}$ results revealed that many participants felt there was little to no appreciation for tasks that were well done. Psychological associates and DAISY Foundation (2009)reported that over seventy percent of nurses reported that they had received no recognition for the work they had done. ${ }^{(9)}$

On the other hand, Lizhang et al., (2019) (27) stated that high percent of nurses were satisfied with contingent praise/ recognition Elsaied (2019) ${ }^{(28)}$ revealed that more than two thirds of head nurses compared to, high percent of nurses were reported moderate level of perception of recognition pattern as total. Degracia et al (2015) (29) revealed that most of the respondents are satisfied with contingent rewards (appreciation, recognition, and rewards for good work done). Eldemerdash and Ghadery (2014) ${ }^{(17)}$ as totally showed that more than seventy percent of nursing managers and more than fifty of their staff nurses had high perception of recognition patterns.

According to Psychological Associates and DAISY Foundation (2009) ${ }^{(9)}$ head nurse use private verbal feedback, public acknowledgement, written acknowledgement, opportunities for growth and participation recognition and compensation pattern of meaningful recognition. Registered nurses preferred to be rewarded for performance through private verbal feedback, written recognition of performance, assistance toward professional goals and participation in unit planning and management activities El-demerdash and Ghadery (2014) ${ }^{(17)}$

The results of the present study at pre educational program; indicated that the majority of head nurses had unsatisfactory level of written acknowledgement. Because of high percent of them not practice all items of written acknowledgement. Also, high percent of head nurses had poor level of written acknowledgement knowledge.Because of high percent of head nurses giving wrong answer for all items of written acknowledgement subscale. This lead to majority of staff nurses had low level of satisfaction regarding head nurses' meaningful recognition practice of written acknowledgement.

This results means that head nurses not believed that quick handwritten note gives meaning to nurses' work, written acknowledgement by posting thank you letters from patients, families and others, sending thank you grams, and personal notes on birth day card are important sources for staff nurses to obtain recognition for their achievement. 
In this regard, Larson \& Hewitt (2012) $)^{(30)}$ found that high percent of staff nurses did not receive written thanks from their supervisors. Nelson \& Economy, (2003) ${ }^{(31)}$ mentioned that almost eighty percent of staff nurses did not received written thanks from their supervisors. Maryanne and Coughlin $(2000)^{(32)}$ reported that written acknowledgement is the valued by nursing managers as others patterns. Cronin\& Becherer (1999) ${ }^{(33)}$ result indicates that nursing managers need to be aware about the importance of offering sincere positive recognition for their staff nurses team.

Ndetei et.al (2016) ${ }^{(34)}$ mentioned that in their study where necessary non - verbal expression such as a smile and active listening will leave a more permanent mark on the feelings and emotions of the staff nursing being appreciated.

Pre educational program, the results of the present study displayed that the majority of head nurses had unsatisfactory level of opportunity for growth and participation practice of meaningful recognition. This may be due to high percent of them not practice all items of opportunity for growth and participation practice, the majority of head nurses had poor level of knowledge about opportunity for growth and participation practice of meaningful recognition, due to high percent of them giving wrong answer for all items of opportunities for growth and participation subscale of meaningful recognition process. As a result, head nurses do not provide staff nurses with opportunities for personal and professional growth. They did not assign staff nurses' new roles beyond their responsibilities, not encourages feeling of achievement or increases motivation to further expand staff nurses' skill mixes. In addition, this result may be related to that head nurses did not believe that their responsibility to provide opportunities to participate on committees, task forces, and interdepartmental work groups and they value opportunities for growth staff nurses and advancement in their positions. Those head nurses do not provide education or training opportunities that expand staff nurses' knowledge and skills.

As well as they did not offer staff nurses chance for participation in committees within or outside their work unit that develop and increase their sense of growth. Accordingly, majority of staff nurses had low level satisfaction regarding head nurses' practice of opportunity for growth and participation meaningful recognition with low mean percent.

According to Fuhrmann (2016) ${ }^{(35)}$ who showed that nurses identify recognition and acknowledgement as fundamental to nurses' 
week, opportunities for growth were considered the most meaningful types of recognition. Kurzen (2001) ${ }^{(36)}$ mentioned that head nurses must have knowledge and skills needed to meet needs of staff nurses. Pre educational intervention results reflected that head nurses are in need for meaningful recognition educational intervention, to improve their related basic knowledge about it. Roberts $(2005)^{(37)}$ revealed that nurses clearly value educational opportunities; more than sixty percent of nurses consider unit based education and 2-hour education opportunities of high value.

Cherry \& Jocob (2002) ${ }^{(38)}$ emphasize that nursing managers must provide opportunities for growth and development, and provide multiple rewards for expertise and opportunities for clinical advancement. Rowland \& Rowland (1997) (39) reported that registered nurses preferred to be appreciated for performance through assistance toward professional goals and participation in unit planning and management tasks

Pre educational program, the results of the present study displayed that the majority of head nurses had unsatisfactory level of public acknowledgment practice of meaningful recognition with low mean percent. Because of high percent of them not practice all items of Because of high percent of them not practice all items of public acknowledgment participation. This is due to majority of head nurses had poor level of public acknowledgment knowledge with low mean percent. Because of high percent of them giving wrong answer for all items of public acknowledgmentof meaningful recognition process. This means that head nurses unaware of public recognition is an important part of the reward as the performance of the individual affects more than just one staff nurses. So, the majority of staff nurses had low level satisfaction regarding head nurses' practice of public acknowledgmentof meaningful recognition process.

In this regard, Winters\& Brooks (2010) ${ }^{(40)}$ revealed that staff nurses value positive public acknowledgement over trinkets, food or certificates. El-demerdash (2006) (16) mentioned that staff nurses responded positively to public recognition, peer reinforcement and senior management appreciation. Cherry \& Jocob (2002) (38) stressed that nursing managers coach counsel, correct subordinates in private and praise them in public. Knox and Gregg (1994) ${ }^{(41)}$ noted that nursing managers who provide public acknowledgement and encouraging a climate of positive 
reinforcement among members create supportive environment.

Pre educational program, the results of the present study displayed that the high percent of head nurses had unsatisfactory level of practice of compensation subscale of meaningful recognition process with low mean percent. Because of high percent of them not practice all items of compensation practice of meaningful recognition. This is due to majority of head nurses had poor level of compensation knowledge with low mean percent, due to high percent of them giving wrong answer for all items of compensation knowledge. This result indicates that head nurses not believed in their responsibility to provide staff nurses special compassionate leave and time, or flexible roster for a particular living needs or family events.

So, El-demerdash and Ghadery (2014) ${ }^{(17)}$ mentioned that nurse manager must be vigilant and persistent when implementing and maintaining appropriate compensation, recognition and reward program. Mamikhani (2014) (42) reported that nursing managers gave less importance while clinical nurse gave more importance to compensation. In this respect, Mwangi (2014) ${ }^{(43)}$ found that many of the respondents were not very aware with the methods used to determine employee compensation at Chloride Exide and they lacked some of the key information of compensation determination. Nyakundi et al (2012) (44) mentioned that relevant studies indicate that the most common problem in most organizations currently is the lack of inclusion of recognition as a component of compensation.

Pre educational program, the results of the present study displayed that more than sixty of head nurses had unsatisfactory level of private verbal feedback practice of meaningful recognition process with low mean percent. Because of high percent of them not practice all items of private verbal feedback. This is due to majority of head nurses had poor level of private verbal feedback knowledge with low mean percent. Because of high percent of them giving wrong answers of all items of private verbal feedback. This means that head nurses not believed in their responsibility to open a feedback channel to staff nurses as private verbal feedback pattern is important source for staff nurses to obtain recognition for their performance. Thus, majority of staff nurses had low level satisfaction regarding head nurses' meaningful recognition practice of private verbal feedback.

This result reflects that head nurses many times do not conscientiously look for good work and not praise it at the time of 
achievement. Most probably they also do not seek opportunities to recognize staff nurses team. Those head nurses need to learn how to create ways to thank or praise in social occasions. Nelson \& Economy, (2003) ${ }^{(45)}$ mentioned that almost sixty of employees had not received verbal thanks from their supervisors.

Similarly, Ibrahim (2019) ${ }^{(46)}$ showed that the majority of the nurses perceived their leaders as low level of the leader organizing feedback dimension and majority of nurses sees their leaders as rarely give the feedback in the proper time. Wagner et al (2015) ${ }^{(47)}$ found that poor personal feedback between nurse managers (operational managers) and professional nurses.

Larson \& Hewitt (2012) ${ }^{(48)}$ found that almost sixty of employees had not received verbal thanks from their supervisors. Radwan (2019) ${ }^{(49)}$ revealed that more than half of nursing staff agree that they are given feedback about changes put into place based on event reported. Roberts(2005) ${ }^{(37)}$ reported that forty to fifty percent of staff nurses said that private verbal feedback is the most common pattern of recognition they received and valued by nursing managers. Also Cherry \& Jocob ( 2002) ${ }^{(38)}$ stressed that nursing managers coach ,counsel ,correct subordinates in private and praise them in public.

Post educational program present study results revealed that significant improvement in head nurses' meaningful recognition practice and knowledge in written acknowledgment, opportunity for growth and participation, public acknowledgment and compensation and private verbal feedback and as totally. This is due to effect of well designed of meaningful recognition program attracted head nurses attention to recognize the importance of meaningful recognition patterns to their staff nurses and evoked their sense of responsibility toward building effective meaningful recognition daily in their units.

According to Suhariyanto et al (2017) ${ }^{(50)}$ training, could help head nurses to upgrade their knowledge and abilities in meaningful recognition in accordance with nursing organizational needs . Furthermore, training could raise head nurses' awareness and change their knowledge from the state of not knowing to the state of knowing. Also, the training focuses on knowledge enhancement instead of balancing the focus on both improving the knowledge and improving psychomotor abilities. Training with active learning methods could effectively 
improve both the knowledge and psychomotor abilities of head nurses in interpersonal relationships and meaningful recognition.

Price-Whelan et al., (2018) ${ }^{(51)}$, Robbins (2006) ${ }^{(52)}$ and Zakria (2001) ${ }^{(53)}$ concluded that education program help head nurses in keeping up to date with new concepts, increasing knowledge and competence, modifying their attitudes and developing their abilities to deal with problems and work with others. So, staff nurses' satisfaction level of head nurses' meaningful recognition practice in total and in all subscales improved at post educational program.

Really the meaningful recognition process educational intervention maximized head nurses' meaningful recognition practice and knowledge in written acknowledgment, opportunity for growth and participation, public acknowledgment and compensation and private verbal feedback and as totally. This was because the educational intervention was planned and implemented according to their pre assessed needs. Additionally, Zakaria (2018) (54) mentioned that program provides head nurses with an opportunity to review their practices, get an objective insight into it and adjust their practices accordingly in the light of peers' opinions in an environment that may be is more comfortable than real life settings.

Furthermore, simplification of well presented information by suitable educational aids increased their interest and desire to acquire recognition knowledge and practice it. The availability of using combined method of teaching helped nursing managers to reach to adequate level of caring knowledge. Dorgham (2005) ${ }^{(55)}$ indicated that using combined teaching methods will provide opportunities for all participants to learn according to their own style.

Concerning relation and correlation

So, result of present study revealed there was significant correlation between head nurses' practice and knowledge of meaningful recognition post educational intervention, with significant correlation of staff nurses' satisfaction regarding head nurses' practice and knowledge of meaningful recognition. This means that the improvement in level of knowledge leads to the improvement in level of practice of meaningful recognition post program as well as staff nurses' satisfaction.

This result was supported by El-demerdash et al., (2018) ${ }^{(56)}$ whose found there were statistical significant correlations between head nurses' total knowledge on political 
leadership and their political leadership skills pre than post program all political leadership skills subscales pre than post program. In this line Mohamed (2019) ${ }^{(57)}$ demonstrates that head nurses' perception toward recognition pattern had no statistically significant correlation with nurses' perception toward recognition pattern used by their head nurses in all domains of recognition pattern. Eldemerdash and Ghadery (2014) (17) demonstrated that, head nurses' perception toward recognition pattern had no statistically significant correlation with nurses' perception toward recognition pattern used by their head nurses in all domains of recognition pattern.

The result of present study revealed there was statistical significant positive relation between head nurses' characteristics and their levels of practice of meaningful recognition process pre, post and 3 months post educational intervention .But, the result of Mohamed(2019) ${ }^{(57)}$ found that head nurses characteristic had no statistical significant relation with overall and all domains of recognition pattern

The result of present study revealed that there was no statistical significant relation between levels of head nurses' knowledge for meaningful recognition process and their characteristics pre ,post and 3 months post educational intervention, except their age and educational level had significant relation with their levels of knowledge post and 3 months post, and pre educational intervention. This could be that the older head nurses were acquired sufficient experiences to offer sincere positive recognition for staff nurses and team, and praising and giving thanks for a job well done.

The results of the present study demonstrated that statistical significant positive relation was found between staff nurses' level of satisfaction regarding head nurses' practice for meaningful recognition and their characteristic pre and post educational intervention except their age had no relation at post educational intervention. This result is consistent with result of El-demerdash and Ghadery (2014) (17) who found that there was significant relationship between levels of staff nurses' recognition patterns and their characteristics. Cherian (2017) ${ }^{(20)}$ found that females with 1-5 years of experience with specialty certification and intent to stay are most likely to have high perceived meaningful recognition. On the other side, the result of Mohamed (2019) ${ }^{(57)}$ found highly statistical significant positive relation was found between staff nurses 
age, years of experience and over all perception toward recognition pattern.

3 months post educational intervention, the result of present study revealed that head nurses' practice and knowledge in written acknowledgment, opportunity for growth and participation, public acknowledgment and compensation and private verbal feedback and as total meaningful recognition slightly decreased than post program .This may related to time factor, the point that some theoretical knowledge that not utilized in regular practice is expected to be decreased, diminished or even lost with passage of time. This indicated the importance of continuous follow up and guidance after program implementation. Planning and implementing training program for head nurses and staff nurses to increase their knowledge and practice is very important as recommended by Shokier (2012) ${ }^{(58)}$,and Ramadan (2015) ${ }^{(59)}$

\section{Conclusion and Recommendations}

\section{Conclusion}

Based on the findings of the present study it was concluded that:

Pre - educational program, the majority of head nurses at Tanta International Teaching Hospital had low level of knowledge about meaningful recognition process and its subscales. They also, had unsatisfactory level of practice in overall meaningful recognition process and its subscales. As a result, the majority of staff nurses low level of satisfaction in overall and in all subscales of head nurses' practice of meaningful recognition process. Immediately after educational program about meaningful recognition, a significant improvement in all head nurses' knowledge and practice of meaningful recognition process was observed. Consequently, staff nurses had high level of satisfaction in total and in all subscales of head nurses' practice of meaningful recognition process. But after three months, head nurses' knowledge and practice were slightly declined.

\section{Recommendations}

On light of the finding obtained from the present study the following were recommended

\section{Top nursing management}

1- Need to pay more attention to the vital role of meaningful recognition process as a valuable strategy for upgrading nurses' job satisfaction.

2- Need to develop policies and practices that foster meaningful recognition process among head nurses.

3- Create a suitable working environment for head nurses to exercise meaningful recognition process and its subscales 
which will lead to many positive outcomes nurses' satisfaction

4- Conduct periodic formal and informal evaluation of head nurses' performance to identify areas of their strengths and weakness to be able to help them in updating their knowledge and skills of meaningful recognition process.

5- Prim importance head nurses' need to attend in-service education programs on meaningful recognition process pre promotion for head nurses position.

\section{References}

1. American Association of Critical Care Nurses. AACN standards for establishing and sustaining healthy work environments: A journey to excellence. American Association of Critical Care Nurses Journal.2005; 187-97.

2. Broughton S. The effectiveness of peer recognition on motivation. American Association of Occupational Health Nurses Journal 2017; 34(12): 596-98.

3. Secord M. How to retain and magnetize registered nurses. Nurse Leader. 2014: 42-44.

4. Gage-Croll Z. Improving hospital patient safety through teamwork: The use of Team STEPPS in critical access hospitals 2011. Retrieved fromhttp://flexmonitoring.org/docume nts/PolicyBrief21_TeamSTEPPS.pdf.

5. Cherian J. Incentives for Health Worker Retention in Kenya. Discussion Paper Series 62. 2017.

6. American Association of Critical-Care Nurses (AACN). AACN Healthy Work Environment assessment. 2016.

7. Froman K. The use of theoretical models in psychology supervisor development research from 1994 to 2010.Canadian Psychology Journal. 2010; 54(1): 176-85

8. Bryant-Hampton L, Walton A. Carroll T, Strickler L. Recognition: a key retention strategy for the mature nurse. Journal of Nursing Administration.2010; 40(3): 121-123. doi:

10.1097/NNA.0b013e3181d04137.

9. Psychological Associates and DAISY Foundation Literature Review on Meaningful Recognition in Nursing.2009.Available at: www.q4solutions.com

10. Havens D, Leeman J. Improving nursing practice and patient care: building capacity with appreciative inquiry. Journal of Nursing Administration.2016; 36(10): 463470. ISSN: 0002-0443 PMID: 17035881. 
11. Carter S. Recognizing the extraordinary work of UC Irvine Healthcare nurses: Structural empowerment. Noteworthy Nursing.2012; 8(1). Retrieved from http://www.healthaffairs.u

12. Djukic M, Greene H. Exploring direct and indirect influences of physical work environment on job satisfaction for early-career registered nurses employed in hospitals. Research in Nursing and Health. 2014; 37: $312-$ 325.doi: 10.1002/nur.21606.

13. Goode J, Blegen A. Development and evaluation of a research-based management intervention. Journal of Nursing Administration.1993; 23: 61-66.

14. Van Bogaert P, Clarke P. The relationship between nurse practice environment, nurse work characteristics, burnout, and job outcome and quality of nursing care. A cross-sectional survey. International Journal of Nursing Studies. 2013; 501667-1677.

15. Ritter D. The relationship between healthy work environments and retention of nurses in a hospital setting. Journal of Nursing Management. 2011; 19(1): 27-32

16. El-demerdash S. Developing caring competences and perception among nursing managers. Unpublished doctoral thesis. Tanta University.2006

17. El-demerdash S, Ghadery S. Assessment of recognition patterns among nursing managers at Tanta University Main Hospital. Zagazig Nursing Journal January.2014;1(10):103-123

18. Williams H, Lewis K. CertificationGood for business. Nephrology Nursing Journal. 2013; 40(3): 247-254

19. Brun J, Dugas N. La reconnaissance au travail: unepratique riche de sens, Quebec, Canada: Chair in Occupational Health and Safety Management. 2002.

20. Cherian G. Hate Spin: The Manufacture of Religious Offense and Its Threat to Democracy . 2016..https://www.amazon.com/HateSpin-Manufacture-ReligiousInformation/dp/0262035308

21. Saunderson R. Survey findings of the effectiveness of employee recognition in the public sector. Public Personnel Management.2004; 33(3):255-275.

22. Zakzouk R. Testing Brooke's causal model of absenteeism on nurses (Unpublished doctoral dissertation).Virginia Commonwealth University, Richmond, VA 2019. 
23. Elsayed J. An analysis of employee recognition: Perspectives on human resources practices Article in The International Journal of Human Resource Management. 2016 DOI: $10.1080 / 09585190801953723$.

24. Asegid A. Study of nurses' job satisfaction: The relationship to organizational commitment, perceived organizational support, transactional leadership, transformational leadership, and level of education. 2016; 22(2):286-295.

25. Elkazeh E, Basal A, Mohamed Knowledge level and Attitude of Nursing Interns toward Patients with Hepatitis C at Tanta University HospitalInternational Journal of Advanced Research 2014; 2( 1): 691-701.

26. Rouse R. Al-maobali M. Identifying nurse managers' essential communication skills: an analysis of nurses' perceptions in Oman", Journal of Nursing Management. 2014; (22)2: 192-200.

27. Shari C. The search for meaning at work. Training and Development. 1997; 51(9):24-27.

28. Elsaied R. Patient care delivery model improves nurse job satisfaction. The Journal of Continuing Education in Nursing.2019; 36(6): 277-282.
29. Degracia A. Dynamic thermal performance of alveolar brick construction system. Energy Conserv. Manage.2015; 52:2495- 500

30. Larson H, Hewitt A. Human resources management (5th ed.). London: Pitman Publishing. 2012.

31. Nelson T. Economy A. Employee attitudes and job satisfaction. Human Resource Management. 2003; 43(4) 395-407.

32. Maryanne M, Coughlin L. Factors influencing satisfaction and anticipated turnover for nurses in an academic medical center. Journal of Nursing Administration. 2000 ; 31(4) : 210-216

33. Cronin S, Becherer D. Recognition of staff nurse job performance and achievements: Staff and managers perceptions. Journal of Nursing Administration.1999; 29(1): 26-31

34. Ndetei D, Mutiso V, Musyimi C, Mokaya A, Anderson K, McKenzie K, Musau A .The prevalence of mental disorders among upper primary school children in Kenya. Social Psychiatry and Psychiatric Epidemiology volume. 2016; 51, :63-71.

35. Fuhrmann D, Knoll L, Blakemore S. Adolescence as a sensitive period of brain development.2016.Trends 

CognSci,
doi:
41. Knox
S, Gregg
A. Balancing
10.1016/j.tics.2015.07.008.
nonmonetary and momentary
36. Kurzen A. A study of nursese job satisfaction: The relationship to organizational commitment, perceived rewards :a contemporary paradigm for nursing. Semin Nurse managers. 1994; (2)3: 140-7. organizational support, transactional leadership, transformational leadership and level of education, European Journal of Scientific Research.2001; 22(2): $286-285$.

37. Roberts R L. The Relationship Between Rewards, Recognition And Motivation at an Insurance Company, In The Western Cape .Master thesis, Department of Industrial Psychology, University of the Western cape 2005.

38. Cherry B, Jocob R. Contemporary nursing: Issues, trends and management. 2nd ed. St. Louis, Mosby Company.2002: 378-39.

39. Rowland H, Rowland B. Handbook of nursing administration. 4th ed ,An aspen publisher .Inc 1979.: 519 .

42. Yildiz Z, Ayhan S, Erdoğmuş S. The impact of nurses' motivation to work, job satisfaction, and socio demographic characteristics on intention to quit their current job: an empirical study in Turkey. Applied Nursing Research.2009; 22 (2):113-8. DOI:

10.1016/j.apnr.2007.06.002 PMID: 19427573

43. Bandiera, O, Larcinese V, Rasul I. (2015) Blissful ignorance?: a natural experiment on the effect of feedback on students' performance. Labour Economics, online: 1-13. ISSN 09275371.DOI:

10.1016/j.labeco.2015.02.002

44. Barankay I. Rank Incentives:

40. Kramer M, Schmalenberg C. Confirmation of a healthy work environment. Critical Care Nurse 2008; (28)2: 56-64. DOI: $10.4037 / \mathrm{ccn} 2008.28 .2 .56$ Evidence from a randomized workplace experiment. 2012. USC FBE APPLIED ECONOMICS WORKSHOP. https://www.researchgate.net/publication $/ 260345423$ 
45. Nelson C, Economy S. Motivational production

function .2014 .https://publications.iad b.org/publications/english/document/F irm-Innovation-and-Productivity-inLatin-America-and-the-CaribbeanThe-Engine-of-EconomicDevelopment.pdfIbrahim P. Factors influencing the retention and turnover intentions of registered nurses in a Singapore hospital. Nursing and Health Sciences.2019; 2: 113-21.

46. Cameron J, Pierce W. Reinforcement, reward, and intrinsic motivation - a meta-analysis. Review of Educational Research. 2015; 64 (3): 363-423.

47. Larson S, Hewitt A. Staff Recruitment, Retention, Training Strategies for Community Human Services Organizations Trainingrtc. 2012.Available at: umn.edu/misc/pubcount.asp?publicati onid $=51$

48. Radwan M. The relationship between effective nurse managers and nursing retention. Journal of Nursing Administration. 2019; 35(7): 336-341. 49. Kovach K. Employee motivation: Addressing a crucial factor in your organization's performance. Employment Relations Today. 1995; 22 (2): 93-107.

50. Price-Whelan A, Sipőcz A, Lim P, Crawford S, Conseil S, et al .The American Astronomical Society. The Astronomical Journal. 2018; (19): 156:123,

Septemberhttps://doi.org/10.3847/153 8-3881/aabc4f@ 2018.

51. Roubbins E. The art of meaningful recognition: Good programs often promote both individual and group behaviors. Occupational Health and Safety. 2006; 74: 48-50

52. Zakeria C. Confirmation of a healthy work environment. Critical Care Nurse. 2001; (28)2: 56-64.

53. Zakeria T. Recognition and staff performance in yumbe district local government, Open Access Publishing Group .Uganda. 2018. Available at: http://www.oapub.org/soc

54. Dorgham K. A., 1995. Employee motivation: Addressing a crucial factor in your organization's performance. Employment Relations Today. 2005; 22 (2), 93-107. 
55. El-demerdash M S, Ghadery $\mathrm{H}$, S.Assessment of recognition patterns among nursing managers at Tanta University Main Hospital. Faculty of nursing. 2018; 10(1) :103-123.

56. Mohamed R .Meaningful recognition and the impact of nurses week activities on recruitment and retention of nurses: The nurses' perspective. 2019: 1-13.barrettdowntown.asu. edu/.../Winters_Spring-2010_Mea. (Date of access20-10-2019)

57. Shokier C. Why stay in nursing. Nursing Management. 2012; 12(9):24-32.

58. Ramadan S. The effectiveness of peer recognition on motivation. American Association of Occupational Health Nurses Journal.2015; 34(12): 596-598. 